\title{
Integrasi Nilai-Nilai Keislaman dalam Pendidikan Antikorupsi Di Sekolah Dasar Muhammadiyah Se-Kapanewon Depok Yogyakarta
}

\author{
Suyitno $^{1)}$, Trisna Sukmayadi ${ }^{2)}$, Jhingga Mahadhni ${ }^{3)}$ \\ ${ }^{1)}$ Universitas Ahmad Dahlan, Yogyakarta, Indonesia. \\ E-mail: suyitno@pgsd.uad.ac.id \\ 2) Universitas Ahmad Dahlan, Yogyakarta, Indonesia. \\ E-mail: trisnasukmayadi@ppkn.uad.ac.id \\ 3) Universitas Ahmad Dahlan, Yogyakarta, Indonesia. \\ E-mail: trisnasukmayadi@ppkn.uad.ac.id
}

\begin{abstract}
Penelitian ini bertujuan untuk mendeskripsikan bagaimana integrasi nilai-nilai Islam ke dalam pendidikan antikorupsi di SD Muhammadiyah Kapanewon Depok Sleman. Populasi dalam penelitian ini adalah 6 guru AIK SD Muhammadiyah se-Kapanewon Depok Sleman yang terdiri dari 2 guru AIK SD Muhammadiyah Condongcatur, 2 guru SD Muhammadiyah Kolombo dan 2 guru AIK SD Muhammadiyah Kayen. Penelitian ini merupakan penelitian lapangan atau field research, dengan jenis penelitian kualitatif. Peneliti terjun langsung ke lapangan untuk mendapatkan data dan informasi tentang integrasi nilai-nilai Islam dalam pendidikan antikorupsi di SD se-Kapanewon, Depok, Sleman. Data disajikan secara deskriptif dengan metode observasi pelaksanaan pendidikan nilai-nilai Islam dan antikorupsi di sekolah dasar, wawancara dengan guru Al-Islam Kemuhammadiyahan, dan dokumentasi pembelajaran sesuai dengan Rencana Pelaksanaan Pembelajaran (RPP). Analisis data menggunakan metode Miles dan Huberman yaitu dengan mengumpulkan data dari lapangan, mereduksi data sesuai dengan kajian teori dan kenyataan di lapangan, dan menyajikan data secara utuh. Hasil penelitian menunjukkan bahwa 1) Nilai-nilai antikorupsi terintegrasi dengan nilai-nilai Islam, baik akhlak, adab maupun keteladanan yang bersifat akhakul karimah. 2) Bagaimana menanamkan dan mengintegrasikan nilai-nilai anti korupsi dan nilai-nilai keislaman melalui semua pembelajaran, khususnya pelajaran kemuhammadiyahan al-Islam. Kesimpulannya, nilai-nilai antikorupsi merupakan bagian dari nilai-nilai Islam yang terintegrasi melalui pelajaran Al Islam kemuhammadiyahan.
\end{abstract}

Keywords: Integrasi, Nilai Islam, Anti Korupsi

\section{PENDAHULUAN}

Kasus korupsi di Negara Republik Indonesia masih tergolong tinggi. Realita ini tak jarang ditemui di berbagai bidang kehidupan, termasuk di antaranya segi hukum, sosial dan politik. Selain itu juga berkaitan dengan karakter sesorang atau norma-norma yang ada di masyarakat. Semua agama yang ada di Indonesia sepakat bahwa korupsi tidak sesuai dengan norma agama masing-masing. Islam sebagai agama mayoritas di Indonesia memandang korupsi sebagai salah satu perbuatan tercela dan merusak tatanan masyarakat. Tindak korupsi bertentangan dengan nilai-nilai dasar Islam yang berlandaskan Al-Qur'an dan hadits yang seharusnya setiap tindakan umatnya menjadi maslahat bagi masyarakat. Pemahaman dan pengamalan ajaran Islam sangat berpengaruh terhadap setiap tindakan. Semakin tinggi tingkat pemahaman dan pengamalan nilai-nilai Islam akan sebanding dengan tingkat kejujuran, sehingga diharapkan mampu menekan tindak korupsi.
Pendidikan antikorupsi merupakan salah satu upaya untuk menekan dan mencegah terjadinya tindak korupsi. Oleh karenanya pendidikan antikorupsi perlu diajarkan pada peserta didik sejak dini, baik diajarkan di rumah oleh orang tua, diajarkan di sekolah oleh guru, maupun di masyarakat sekitar. Hal ini sesuai dengan hasil penelitian Sumaryati dan $T$. Sukmayadi (2017), bahwa kontribusi aksiologi pendidikan antikorupsi dalam mengembangkan sikap antikorupsi terbagi dalam tiga ranah, yaitu sikap antikorupsi di dalam keluarga, didalam kelas, dan tengah masyarakat.

Dalam ranah didalam kelas, Guru mempunyai tugas untuk menanamkan nilai-nilai antikorupsi kepada peserta didik dalam kegiatan belajar mengajar maupun dalam kegiatan ekstrakurikuler. Hal ini diperkuat oleh Suyitno dan Y. Hidayah (2019), bahwa strategi guru dalam menanamkan nilai-nilai anti korupsi dapat melalui kegiatan di luar kelas, contoh dari guru berupa keteladanan, dan pembudayaan nilainilai antikorupsi dalam setiap aktivitas dan keadaan di lingkungan sekolah. Salah satu upaya mengintegrasikan nilai keislaman dan pendidikan antikorupsi yaitu melalui 
pembelajaran di kelas. Suyitno dan T. Sukmayadi (2019) menguatkan bahwa tugas guru seharusnya mengajarkan nilainilai antikorupsi di kelas pada setiap pembelajaran sehingga peserta didik mampu memahami dan mengamalkan nilai-nilai antikorupsi dalam kesehariannya.

Nilai-nilai Islam merupakan hal mutlak yang menyangkut aspek jasmani dan rohani, yang bertujuan mengatur dan menjaga makhluk agar tetap sesuai dengan fitrahnya. Nilai-nilai tersebut menyangkut prinsip hidup dan dasar kehidupan manusia yang berlandasakan pada Al-Qur'an dan hadits agar selamat dunia akhirat. Nilai-nilai Islam dipengaruhi oleh beberapa nilai utama, di antaranya akhlak, adab, dan keteladanan. Majid dan Andayani (2012) menjelaskan bahwa dalam Islam terdapat tiga nilai utama, yaitu akhlak, adab, dan keteladanan. Nilai akhlak mengacu pada tugas dan tanggung jawab selain aspek syari'ah dan ajaran Islam secara umum. Nilai adab mengacu pada sikap yang dikaitkan dengan tingkah laku yang baik. Dan nilai keteladanan mengacu pada kualitas karakter yang ditampilkan oleh seorang muslim yang baik dengan cara meneladani Nabi Muhamad SAW. Ketiga nilai tersebut yang menjadi pondasi pendidikan karakter dalam Islam.

Justiana (2014) menyebutkan bahwa ada 9 nilai antikorupsi berdasarkan rumusan KPK yang harus dilaksanakan yaitu jujur, disiplin, tanggung jawab, adil, berani, peduli, kerja keras, sederhana, dan mandiri. Semua nilai-nilai antikorupsi tersebut harus difahami dan diimplementasikan dalam kehidupan sehari-hari dalam rangka mengurangi kasus korupsi yang semakin merajalela. Pada hakikatnya nilai-nilai antikorupsi sejalan nilai-nilai islam, karena merupakan bagian yang tidak terpisahkan. Suyitno (2017), menjelaskan bahwa ada nilai-nilai islam yang termuat dalam pendidikan antikorupsi yaitu nilai kejujuran, kedisiplinan, tanggungjawab, keadilan, keberanian, kepedulian, kerja keras, kesederhanaan, dan kemandirian merupakan akhlakul karimah.

Hakim (2012) mengemukakan ada dua macam model yang dapat dilakukan oleh pihak sekolah dalam menyeimbangkan kurikulum pendidikan yang terintegrasi pada pendidikan agama. Model pertama, bahwa proses pendidikan harus mampu menumbuhkan sikap kepedulian sosial-normatif, membangun penalaran obyektif, dan mengembangkan perspektif menyeluruh pada individu. Model kedua, pendidikan harus mengarah pada penyemaian strategis, yaitu kualitas individu yang konsekuen dan kokoh dalam keterlibatan peran sosialnya. Hal ini menandakan bahwa pendidikan agama merupakan dasar pendidikan secara umum, salah satunya pendidikan antikorupsi. Agama merupan pondasi dalam pendidikan karakter yang terintegrasi dalam pendidikan antikorupsi.

Manurung (2012) juga menguatkan tentang pendidikan antikorupsi yang terintegrasi dengan mata pelajaran PAI dapat berjalan dengan efektif jika melalui jalur pendidikan dan keyakinan beragama. Pada jalur ini pola pembinaan pengetahuan dan mental terhadap siswa, khususnya di kalangan remaja sudah terarah sehingga mampu mengubah mentalitas peserta didikjika dilakukan dengan totalitas sepenuh hati, bukan hanya sekedar formalitas atau kepura- puraan. Penguatan pendidikan antikorupsi dan PAI perlu diberikan sejak dini salah satunya di sekolah dasar atau di madrasah ibtidaiyah. Kementerian Agama terus berupaya untuk memberikan pemahaman kepada masyarakat dalam rangka penguatan keyakinan beragama yang sejalan dengan nilai-nilai antikorupsi. Secara spesifik pendidikan antikorupsi yang dirumuskan oleh Kementrian Agama RI (2013), yakni (1) menanamkan nilai-nilai dan sikap hidup antikorupsi kepada seluruh warga sekolah (2) menumbuhkan kebiasaan (habit) perilaku antikorupsi kepada warga sekolah, dan (3) mengembangkan kreativitas warga sekolah dalam memasyarakatkan dan membudayakan perilaku antikorupsi di lingkungan sekolah.

Di sisi lain Agus Wibowo (2013) menguatkan bahwa pengembangan pendidikan antikorupsi yang diintegrasikan ke dalam mata pelajaran, pengembangan diri, dan budaya sekolah. Sehingga nilai-nilai acuan pendidikan antikorupsi harus diintegrasikan ke dalam Rencana Pelaksanaan Pembelajaran. Selain itu, berdasarkan hasil pengembangan model pendidikan antikorupsi yang dilakukan oleh Daulay (2013) bahwa implementasi model pendidikan antikorupsi melalui media komik sebagai salah satu media pembelajaran yang menunjukkan peningkatan pemahaman peserta didiktentang pengertian korupsi dan cara mengatasinya. Dengan demikian perlu adanya dukungan dari semua elemen masyarakat guna menekan tindak korupsi. Elemen masyarakat yang berperan penting dalam hal ini di antaranya warga sekolah.

Berdasarkan observasi di Sekolah Muhammadiyah sekapanewon Depok sudah mengintegrasikan nilai islam dengan pendidikan antikorupsi khususnya nilai kejujuran. Hal ini terlihat dalam program kantin kejujuran. Oleh karena itu perlu dilakukan penelitian yang lebih mendalam. Penelitian ini bertujuan untuk mendeskripsikan integrasi nilai-nilai keislaman dalam pendidikan antikorupsi di Sekolah Dasar Muhamadiyah se-Kapanewon Depok Sleman.

\section{MetodE}

Populasi dalam penelitian ini adalah sebanyak 6 Guru AIK di SD Muhammadiyah Se-Kapanewon Depok Sleman yang terdiri dari 2 Guru AIK SD Muhammadiyah Condongcatur, 2 Guru SD Muhammadiyah Kolombo dan 2 Guru AIK SD Muhammadiyah Kayen. Penelitian ini merupakan penelitian lapangan atau field research, dengan jenis penelitian kualitatif. Peneliti langsung terjun ke lapangan untuk mendapatkan data dan informasi tentang integrasi nilainilai keislaman dalam pendidikan antikorupsi di Sekolah Dasar se-Kapanewon Depok Sleman.

Data disajikan secara deskriptif dengan metode observasi tentang pelaksanaan nilai-nilai keislaman dan pendidikan antikorupsi di sekolah dasar, wawancara bersama guru Al-Islam Kemuhammadiyahan, dan dokumentasi pembelajaran yang sesuai dengan rencana pelaksanaan pembelajaran (RPP). Data dianalisis dengan metode Miles dan Huberman (2014) yaitu dengan cara mengumpulkan data yang berasal dari lapangan, mereduksi data sesuai dengan kajian 
teori dan realita di lapangan, dan menyajikan data secara utuh..

\section{HASIL DAN PEMBAHASAN}

Berdasarkan observasi di lapangan, wawancara dengan guru Al Islam Kemuhammadiyahan dan dokumentasi melalui RPP di SD Muhammadiyah se-Kapanewon Depok Sleman Yogyakarta didapatkan hasil bahwa nilai-nilai antikorupsi terintegrasi dengan nilai-nilai Islam yaitu akhlak, adab maupun keteladanan yang merupakan akhlakul karimah serta diintegrasikan melalui pelajaran $\mathrm{Al}$ Islam Kemuhammadiyahan.

\section{Integrasi Akhlak dan Nilai Antikorupsi}

Salahudin (2018) memaparkan bahwa Pendidikan akhlak dan antikorupsi merupakan hal paling dasar dengan memberikan pendidikan dari aspek pengetahuan saja namun lebih kepada aspek tingkah laku. Hal ini sejalan dengan kehidupannya yang perlu dikenalkan sejak awal agar mampu menjalani kehidupan dengan baik. Hasil wawancara dengan guru Al Islam Kemuhammadiyahan (AIK) Bapak AM tentang integrasi akhlak dan nilai antikorupsi di Sekolah Dasar Muhammadiyah menyebutkan bahwa adanya integrasi yang sangat erat sebagaimana pernyataannya sebagai berikut:

"Korupsi merupakan salah satu bentuk pelanggaran terhadap nilai-nilai akhlak (jujur, disiplin, tanggungjawab, adil, berani, peduli, kerjakeras, sederhana, dan mandiri). Oleh karena itu nilai antikorupsi dapat diintegrasikan dengan akhlak". (Wawancara dengan guru AIK SD Muhammadiyah Komplek Kolombo, 07 Juli 2021)

Oleh karena itu nilai antikorupsi dapat diintegrasikan dengan akhlak. Integrasi akhlak sangat berpengaruh terhadap nilai antikorupsi. Nilai-nilai antikorupsi merupakan bagian dari akhlak, yaitu akhlaqul karimah. Hal ini menunjukkan adanya integrasi antara nilai antikorupsidengan akhlak.

Diperkuat oleh Bapak SU bahwa:

"Nilai anti korupsi tersebut merupakan bagian dari akhlak, yaitu akhlaqul karimah. Jadi sudah terintegrasi antara nilai anti korupsi dengan akhlak". (Wawancara dengan guru AIK SD Muhammadiyah Condongcatur, 09 Juli 2021).

Dari wawancara tersebut menggambarkan bahwa nilai-nilai antikorupsi yang terintegrasi dengan akhlak baik dapat mengindikasikan bahwa individu tersebut telah menjalankan nilai antikorupsi dengan baik. Ketika individu memiliki akhlak yang buruk bisa diindikasi melakukan halhal yang akan menimbulkan tindakan korupsi. Seorang guru jika mengetahui peserta didiknya memiliki akhlak yang kurang baik bisa memberikan arahan dan membimbing peserta didik tersebut dengan menanamkan nilai antikorupsi berbasis nilai-nilai islam.

\section{Integrasi adab dan Nilai Antikorupsi}

Kholid (2017) mendefinisikan bahwa adab merupakan pengetahuan yang dapat menjaga dirinya dari perbuatan yang salah. Adab mencerminkan bagus tidaknya seseorang sehingga adab dapat menjadikan seseorang menjadi mulia disisi Allah SWT. Hal ini sejalan apa yang disampaikan oleh Bapak SU tentang integrasi antara adab dengan nilai antikorupsi. Sebagaimana pernyataannya sebagai berikut:

"Nilai anti korupsi yang ada itu bagian dari apa yang diajarkan oleh oleh Allah dan rasulnya, tinggal manusianya yang mengamalkannya". (Wawancara dengan guru AIK SD Muhammadiyah Condongcatur, 09 Juli 2021).

Dari hasil wawancara tersebut dapat dijabarkan bahwa nilai antikorupsi dalam integrasi adab merupakan bagian dari apa yang diajarkan oleh Allah dan rasul-Nya. Nilai tersebut dapat terealisasi jika manusianya memahami nilai-nilai dan mengamalkannya. Ketika sebagai manusia tidak mempunyai keinginan untuk memahami atau mengamalkan maka tidak akan tercapai nilai antikorupsi dalam integritas adab.

Ibu NIR juga menambahkan bahwa pengintegrasian nilai adab dan nilai antikorupsi sudah baik dilaksanakan di Sekolah. Berikut pernyataanya:

"Penerapan adab disekolah sudah mencapai kata "baik". Peserta didik telah diajarkan norma atau aturan tentang anti korupsi”. (Wawancara dengan guru AIK SD Muhammadiyah Kayen, 07 Juli 2021). Dari pernyataan diatas menunjukkan bahwa penerapan adab di sekolah sudah sudah baik. Peserta didik telah diajarkan norma atau aturan tentang antikorupsi. Norma- norma tentang antikorupsi diselipkan dalam mata pelajaran peserta didikterutama Al Islam Kemuhammadiyahan. Selain itu, di sekolah juga diterapkan aturan yang menjerumus ke nilai antikorupsi diantaranya peserta didik wajib memakai seragam yang sesuai ketentuan, dilarang menyontek ketika ujian, dan wajib mengikuti upacara bendera setiap hari senin. Dengan menyelipkan aturan dan norma antikorupsi di sekolah dapat membuat peserta didikmengerti pentingnya antikorupsi. Adanya integrasi adab dengan nilai antikorupsi (jujur, disiplin, tanggungjawab, adil, berani, peduli, kerjakeras, sederhana, dan mandiri) sangat diperlukan, sebab korupsi bertentangan dengan adab Islam.

\section{Integrasi Keteladan dan Nilai Antikorupsi}

Hasbullah (2012:29) keteladanan merupakan tata cara bertingkah laku yang akan ditirukan oleh peserta didik sehingga akan menjadi pengaruh positif dengan yang ditirukan. Menurut Bapak MW mengatakan:

"Integrasi keteladanan dengan nilai anti korupsi (jujur, disiplin, tanggungjawab, adil, berani, peduli, kerja keras, sederhana dan mandiri) yaitu harus dimodelkan atau diberi contoh sebagai wujud keteladanan, sehingga mudah ditiru. Hal ini penting keteladan guru (digugu dan ditiru), guru adalah model hidup yang sangat efektif dan efisien untuk 
dijadikan teladan bagi anak didik". (Wawancara dengan guru AIK SD Muhammadiyah Condongcatur, 08 Juli 2021).

Dalam mengajarkan nilai antikorupsi maka lebih efektif dan mengena kalau dengan menggunakan keteladanan, terutama untuk anak SD. Baik, keteladanan peserta didik dalam nilai antikorupsi telah tercapai. Untuk guru dan karyawan keteladanan dalam nilai antikorupsi juga tercapai dengan baik. Begitupun dengan integrasi keteladanan sangat selaras. Keteladanan di sini dimasukkan pada model yang bisa ditiru oleh anak yang hanya bisa melihat dari apa yang nyata bagi dunia anak. Keteladanan ini bisa dengan memunculkan sesosok yang patut ditekadani oleh pesertadidik. Nantinya peserta didik akan menirunya.

\section{Bapak AM juga menguatkan bahwa}

"Salah satu keberhasilan pendidikan adalah adanya keteladanan, sehingga integrasi keteladanan dengan nilai antikorupsi (jujur, disiplin, tanggungjawab, adil, berani, peduli, kerjakeras, sederhana, dan mandiri) merupakan cara yang cukup efektif untuk dilakukan". (Wawancara dengan guru AIK SD Muhammadiyah Komplek Kolombo, 07 Juli 2021)

Integrasi keteladanan dengan nilai antikorupsi (jujur, disiplin, tanggungjawab, adil, berani, peduli, kerja keras, sederhana dan mandiri) yaitu harus dimodelkan atau diberi contoh sebagai wujud keteladanan, sehingga mudah ditiru. Hal ini penting keteladan guru (digugu dan ditiru), guru adalah model hidup yang sangat efektif dan efisien untuk dijadikan teladan bagi anak didik. Keteladan dari orang tua dan guru merupakan hal yang sering diperhatikan oleh anak. Ketika di rumah anak akan sering memerhatikan sikap dan perbuatan yang dilakukan kedua orangtuanya. Orang tua juga perlu memerhatikan perbuatan yang dilakukannya agar tidak menjadi contoh buruk untuk anaknya. Orangtua juga bisa belajar memahami konsep dan nilai-nilai antikorupsi untuk menjadi teladan anaknya ketika di rumah. Orang tua bisa menerapkan pembiasaan mulai dari hal-hal kecil. Seperti bertindak jujur dan bertanggung jawab atas dirinya sendiri.

\section{Cara Mengintegrasikan Akhlak dan Nilai Antikorupsi}

Nilai antikorupsi merupakan bagian atau sudah tercakup dalam akhlaq maka tinggal memberikan penekanan saja dengan cara memberitahu, mengajarkan, mendiskusikan dan mensosialisasikan tentang akhlak yang baik yaitu jujur, disiplin, tanggung jawab, adil, berani, peduli, kerja keras, sederhana dan mandiri. Hal ini sebagaimana yang disampaikan oleh Bapak AHR:

"Dengan cara memberitahu, mengajarkan, mendiskusikan dan mensosialisasikan tentang akhlak yang baik yaitu jujur, disiplin, tanggung jawab, adil, berani, peduli, kerja keras, sederhana dan mandiri. (Wawancara dengan guru AIK SD Muhammadiyah Komplek Kolombo, 07 Juli 2021)

Dari pernyataan diatas jelas bahwa nilai-nilai tersebut diterapkan dalam kehidupan sehari-hari baik dalam tulisan, lisan maupun perbuatan. Hal ini terlihat dari peran guru untuk menekankan kepada peserta didik dalam mengerjakan setiap tugas rumahnya secara jujur. Kegiatan seperti mencontek, plagiarisme, dan menitip presensi merupakan tindakan tidak jujur yang dapat menimbulkan perilaku korupsi. Kegiatan tidak jujur seperti ini merupakan hal yang perlu diperhatikan dengan serius agar nantinya kebiasaan tersebut tidak berlanjut ketikasudah dewasa.

Senada dengan pernyataan diatas, Bapak RY mengatakan bahwa dalam mengintegrasikan akhlak dan nilai antikorupsi sebagai berikut:

"Menerapkan nilai dalam kehidupan sehari-hari. Baik dalam tulisan, maupun lisan dan perbuatan. Seperti nilai jujur, guru-guru menekankan kepada muridmurid untuk mengerjakan setiap tugas rumahnya secara jujur, begitu juga nilai peduli, seperti dalam acara perpisahan murid, ataupun ketika ada musibah, baik guru-guru maupun anak-anak dan para wali murid bekerjasama untuk bahu membahu". (Wawancara dengan guru AIK SD Muhammadiyah Kayen, 07 Juli 2021)

Selain itu, nilai peduli ketika ada musibah, baik guru-guru maupun anak-anak dan para wali murid bekerjasama untuk bahu membahu. diberi tanggung jawab mengerjakan tugas dilaksanakan secara mandiri, kemudian dikumpulkan pada waktunya sebagai wujud disiplin. Ketika peserta didik sudah terlatih disiplin dan bertanggung jawab akan membuat peserta didik mudah dalam mencapai tujuan dan mengefisien waktu karena disiplin.

Seseorang yang disiplin dan bertanggung jawab dapat membuat orang lain percaya terhadap dirinya. Hal ini memang sepele namun sangat berdampak luar biasa pada akhirnya. Karena suatu kebiasaan yang baik jika terus dilakukan maka akan menghasilkan kebaikan yang besar. Pribadi peserta didik yang adil dan berani misalnya ketikasaat ujian teman-temannya melakukan penyimpangan dengan mencontek, ia akan berani berdiri sendiri dengan kebenaran dengan tidak ikut mencontek seperti temannya yang lain. Ia tidak akan takut jika dimusuhi dan tidak takut jika ditinggal temannya yang mengajak kepada hal yang menyimpang. Ia juga akan menerima hasil sesuai jerih payahnya dan tidak akan memaksakan untuk dapat hasil yang lebih dari apa yang telahdiusahakan.

Peserta didik dapat menerapkan nilai sederhana di sekolah seperti hidup sesuai kebutuhan dan tidak memamerkan kekayaannya. Sifat mandiri pada peserta didikdapatmembuat ia tidak mudah bergantung kepada orang lain. Dengan demikian cara mengintegrasikan akhlaq dengan nilai antikorupsi yaitu dengan menurunkan nilai akhlaq pada sikap kehidupan nyata, yang bisa dilaksanakan pada kehidupan sehari hari, hal itu sudah termasuk sikap antikorupsi.

\section{Cara Mengintegrasikan Adab dan Nilai Antikorupsi}

Nilai antikorupsi tersebut sudah termasuk dalam ajaran Allah dan Rasul dam Al-Qur'an dan Hadits. Yang diperlukan saat ini adalah memberikan penekanan terhadap nilai-nilai tersebut. Bapak RY mencontohkan: 
"Salah satunya dengan menerapkan dalam kehidupan sehari-hari, seperti bersapa sopan bila bertemu dengan guru, mengucapkan salam bertemu guru, dan sebagainya". (Wawancara dengan guru AIK SD Muhammadiyah Kayen, 07 Juli 2021)

Selain itu, mengintegrasikan adab dan nilai antikorupsi dengan cara memberi tahu, mengajarkan dan mensosialisasikan tentang adab jujur, disiplin, tanggung jawab, adil, berani, peduli,kerja keras, sederhana dan mandiri. Hal ini sejalan dengan Bapak MW bahwa:

"Cara mengintegrasikan adab dengan nilai antikorupsi yaitu dengan mengkongkritkan sikap bertatakrama dari sikap nilai antikorupsi, misalnya kerja keras sebagai adab seseorang yang ingin mencapai cita- citanya". (Wawancara dengan guru AIK SD Muhammadiyah Condongcatur, 08 Juli 2021).

Dengan demikian maka akan tercapai integrasi adab dengan nilai antikorupsi didalam menjalankan kehidupan sehari-hari. Hal ini dapat dilakukan dengan menerapkan norma atau aturan antikorupsi dengan cara memperkuat budi pekerti, perangai tingkah laku yang sesuai sehingga akan menjadikan pendidikan antikorupsi sebagai adab islami.

\section{Cara Mengintegrasikan Keteladanan dan Nilai Antikorupsi}

Al-Tadzkiyyah. (2017) menyebutkan bahwa pendidikan antikoroupsi di sekolah dengan memberikan keteladanan bisa dengan sebagai guru yang mengajar memberikan contoh bagaimana sikap antikorupsi itu agar peserta didik bisa belajar dari sikap guru tersebut. Menjelaskan bagaimana manfaat dari bersikap antikorupsi dan hal baik apa saja yang ada didalamnya dapat menimbulkan kemauan dan membuat peserta didik tertarik untuk bersikap antikorupsi. Agar peserta didik tidak merasa bosan dengan teori saja, maka perlu dilakukan kreatifitas dalam membangun sikap antikorupsi bisa dengan membuat poster kreatifitas atau lomba pidato antikorupsi yang mengundang bisa mengundang kratifitas peserta didikjuga. Jika di dalam pendidikan informal seperti lingkungan keluarga bisa dilakukan dengan memperlakukan anak dengan adil satu sama lain. Pembiasaan dalam keluarga dengan bersikap deomkratis juga bisa dilakukan untuk menanamkan nilai antikorupsi seperti pada saat ingin liburan maka semua anggota keluarga bermusyawarah untuk menentukan tujuan liburan. Jika salah satu pendapat anggota keluarga belum diterima maka perlu bersikap lapang.

Seorang guru dituntut untuk bisa menjadi teladan bagi muridnya untuk melakukan nilai-nilai antikorupsi (kalau di sekolah), Sedangkan kalau di rumah harus bekerja sama dengan orang tua. Hal ini disampaikan oleh Ibu NIR sebagai berikut:

"Membiasakan berucapan, bersikap, dan berperilaku yang melekat pada seorang pendidik". (Wawancara dengan guru AIK SD Muhammadiyah Kayen, 07 Juli 2021).

Oleh karena itu, guru dan orang tua perlu kerjasama dalam menampilkan contoh-contoh perbuatan korupsi dan akibat dari perbuatan korupsi, baik akibat di dunia maupun akibat di akhirat. Contoh penerapan pembiasaan ketika dirumah saat anak disuruh membeli barang di warung dan uang yang diberikan ternyata sisa namun tidak dikembalikan kepada ibunya. Maka sebagai orang tua patut menanyakan kepada anak keberadaan uang tersebut dan kenapa anak tidak memberikan uang kembalian kepadanya. Hal ini perlu ditelusuri agar tidak menjadi pembiasaan kepada anak mengambil sesuatu yang sebenarnya bukan hak miliknya. Selain itu, Bapak AHR mengatakan cara mengintegrasikan keteladanan dengan nilai antikorupsi sebagai berikut:

"Dengan cara memberitahukan dan mensosialisasikan akan pentingnya keteladanan kaitannya dengan nilai antikorupsi (jujur, disiplin, tanggung jawab, adil, berani, peduli, kerja keras, sederhana dan mandiri)". (Wawancara dengan guru AIK SD Muhammadiyah Komplek Kolombo, 07 Juli 2021)

Salah satunya dalam kehidupan keseharian warga sekolah untuk mengutamakan pentingnya nilai- nilai antikorupsi sebagaimana ajaran Islam menyeru kepada penganutnya. Seperti nilai jujur, yang mana baginda Rasulullah SAW. Pun dikenal sebagai ash-shoodiq, dan sebagainya. Cara mengintegrasikan keteladan dengan nilai antikorupsi yaitu guru melaksanakan dan membiasakan nilai antikorupsi sehingga sudah menjadi karakter di dalam diri guru, baru memulai menjadi teladan terhadap anak didiknya.

Penanaman nilai antikorupsi di sekolah dapat menggunakan beberapa pendekatan. Pendayagunaan media Pendidikan melalui penanaman nilai antikorupsi merupakan salah satunya. Kegiatan belajar mengajar perlu menerapkan jenis dan bentuk kegiatan belajar mengajar yang bisa mengikuti perkembangan zaman, seperti halnya di negara Indonesia yang saat ini sedang marak dengan angka korupsi, korupsi yang sudah menjadi budaya dan tradisi bagi kalangan atas maupun bawah. Cara mengintegrasikan keteladan dengan nilai antikorupsi yaitu guru melaksanakan dan membiasakan nilai antikorupsi sehingga sudah menjadi karakter di dalam diri guru, baru memulai menjadi teladan terhadap anak didiknya. Sebelum menjadi suri tauladan terhadap peserta didik, guru perlu merefleksi dirinya terlebih dahulu. Merefleksikan apa yang tidak boleh guru lakukan agar tidak dicontoh peserta didiknya.

Seorang guru juga perlu memahami bentuk integrasi dari keteladanan antikorupsi. Jika seorang guru melakukan tindak penyelewengan yang bertolak belakang dengan nilai-nilai antikorupsi dan siswanya melihat hal tersebut, maka akan berbahaya. Peserta didikbisa menganggap bahwa apa yang dilakukan guru tersebut benar lalu mencontohnya dan melakukan Tindakan penyelewengan seperti apa yang dilakukan oleh guru tersebut.

\section{KESIMPULAN}

Berdasarkan pembahasan dan hasil penelitian tentang integrase nilai islam dan nilai antikorupsi di SD Muhammadiyah se-Kapanewon Depok Sleman maka dapat disimpulkan bahwa nilai antikorupsi merupakan bagian dari 
nilai islam yang terintegrasi melalui pelajaran $\mathrm{Al}$ Islam kemuhammadiyahan. Dalam pembelajarannya lebih menekankan pada proses keteladanan akhlakul karimah. Cara mengintegrasikan nilai islam dan nilai antikorupsi melalui pembelajaran Al Islam Kemuhammadiyahan baik di kelas maupun diluar kelas dengan melibatkan seluruh warga sekolah termasuk orangtua peserta didik

\section{DAFTAR PUSTAKA}

[1] Sumaryati dan T. Sukmayadi (2017). Kontribusi aksiologi pendidikan antikorupsi dalam mengembangkan sikap antikorupsi mahapeserta didikprogram studi PPKn. Makalah seminar nasional di UAD, 27 November 2017.

[2] S. Suyitno dan Y. Hidayah. (2019). Strategi guru dalam menanamkan nilai-nilai anti korupsi di SD Muhammadiyah Wirobrajan 3 Yogyakarta. Makalah Seminar Nasional Pagelaran Pendidikan Dasar Nasional di UAD, 30 Januari 2019.

[3] S. Suyitno dan T. Sukmayadi. (2019). Madrasah Antikorupsi TPA di Kecamatan Depok Sleman Yogyakarta. Makalah Seminar nasional Hasil Pengabdian kepada masyarakat di Universitas Ahmad Dahlan Yogyakarta, 14 September 2019.

[4] Majid, A. \& Andayani, D. (2012). Pendidikan Karakter Perspektif Islam. Bandung: Remaja Rosdakarya.

[5] Justiana, Sandri, dkk. (2014). Buku ajar pendidikan dan budaya antikorupsi (PBAK). Jakarta: Pusat pendidikan dan pelatihan Tenaga Kesehatan.

[6] Hakim, L. (2012). Model Integrasi Pendidikan Anti Korupsi dalam Kurikulum Pendidikan Islam. Jurnal Pendidikan Agama Islam-Ta'lim. 10(2):141-156.

[7] Manurung, Rosida Tiurma. (2012). Jurnal Pendidikan Anti korupsi Sebagai Satuan Pembelajaran Berkarakter dan Humanistik. Jurnal Sosioteknologi. XXVII (11), 234

[8] Kemenag RI. (2013). Panduan penyenggaraan pendidikan antikorupsi di madrasah. Jakarta: Direktorat Jenderal Pendidikan Islam.

[9] Agus, Wibowo. (2013). Pendidikan Antikorupsi di Sekolah: Strategi Internalisasi Pendidikan Antikorupsi di Sekolah. Yogyakarta: Pustaka Belajar.

[10] Daulay. (2013). Pengembangan Model Pendidikan Antikorupsi melalui Media Komik bagi Peserta didikSD. Jurnal Sekolah Dasar. 22(1): 28-4

[11] Miles, M.B., Huberman, A. M., \& Saldana, J. (2014). Qualitative Data Analysis, A Methods Sourcebook (Terjemahan) (Edition 3). UI-Press.

[12] Salahudin, Anas. (2018). Pendidikan Antikorupsi. Bandung: Pustaka Setia

[13] Kholid, A. R. I. (2017). Ilmu Akhlak Suatu Pengantar. Diktat. IAIN Syekh Nurjati Cirebon.

[14] Hasbullah. (2012) Dasar-dasar Ilmu Pendidikan, Jakarta: PT. Raja Grafindo Persada.

[15] Al-Tadzkiyyah. (2017). Pendidikan Anti Korupsi dalam Pendidikan Agama Islam. Jurnal Pendidikan Islam, Vol 9, No I . 